\title{
Ethics Principles, Personal Values, And Ethical Judgment
}

Gary Saunders, Marshall University

Loren Wenzel, Marshall University

\begin{abstract}
Researchers have conducted various studies in an attempt to gain insights into the ethics of business leaders to postulate possible reasons for unethical behavior. Recent scandals such as Enron, Worldcom, and Adelphia indicate an ethical problem still exists in the business community. Business ethics are typically discussed at length in university business programs, sometimes with one or more courses devoted to the topic. Very often students are used as surrogates for business leaders. One such study by Ahmad and Fadzly $(A \& F$, 2004) posited that when a person observes what they consider to be an unethical act they will try to explain (ethical judgment) why the individual acted unethically. The person would then either endorse the action as acceptable in the circumstances or reject it as unacceptable. Their ethics principles and personal values would supposedly influence that decision. Additionally, the authors suggest that the perceived consequences of the unethical act would have an influence. This study is an attempt to replicate the A \& F study, using accounting and business students in the United States (their study was conducted with Malaysian students). Ahmad and Fadzly's questionnaire was modified and administered to 418 university business and accounting students. The questionnaire contained 19 questions, randomly arranged, that related to five factors. Respondents in the present study indicated a high level of ethics principles and personal values, and females displayed higher level personal values. The ethical judgment scale reflects the level of acceptance of (making excuses for) unethical acts and less than $20 \%$ of the participants in the present study indicated that they would agree that the unethical acts contained in the scale were acceptable in the environment described. Almost 60\% of the respondents in the present study believed that they would experience positive consequences from unethical actions and a similar number, 56.13\%, believed that they would experience negative consequences from unethical actions.
\end{abstract}

\section{INTRODUCTION}

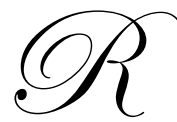

esearchers have conducted various studies in an attempt to gain insights into the ethics of business leaders to postulate possible reasons for unethical behavior. Recent scandals such as Enron, Worldcom, and Adelphia indicate an ethical problem still exists in the business community. Business ethics are typically discussed at length in university business programs, sometimes with one or more courses devoted to the topic. Very often students are used as surrogates for business leaders. One such study by Ahmad and Fadzly (A \& F, 2004) posited that when a person observes what they consider to be an unethical act they will try to explain (ethical judgment) why the individual acted unethically. The person would then either endorse the action as acceptable in the circumstances or reject it as unacceptable. Their ethics principles and personal values would supposedly influence that decision. Additionally, the authors suggest that the perceived consequences of the unethical act would have an influence.

This study is an attempt to replicate the A \& F study, using accounting and business students in the United States (their study was conducted with Malaysian students). Ahmad and Fadzly's questionnaire was modified and administered to 418 university business and accounting students. The questionnaire contained 19 questions, randomly arranged, that related to five factors. 


\section{PREVIOUS STUDIES}

The large number of studies relating to the ethics of business and accounting students is probably due to the inability of researchers to explain human behavior. Studies by Cohen et a1. (2001), O'Leary and Cotter (2000), Glover et a1. (2002), Sankaran and Bui (2003), Allmon et. a1. (2000), attempted to determine factors, such as demographic characteristics, personal values, cultural differences, that might influence ethical behaviors. Allmon et al. (2000) studied some factors that might affect business students' ethical beliefs and their perceptions of ethical classroom behavior. They considered attitudes toward cheating in the classroom as an indication of future business ethics. Their results indicated differences in ethical behavior based on personality preferences, country of origin, age, religious orientation and gender.

O'Leary and Cotter (2000) examined the ethical attitudes of final year accountancy students in Ireland and Australia in an effort to determine if culture has an effect on ethical decision-making. The survey instrument contained six ethical scenarios each with three choices of action. Participants could either accept a bribe/offer, reject the bribe/offer and say nothing, or reject the bribe/offer and report to the relevant authorities. Irish students were found to be more ready to act unethically than were their Australian contemporaries. Additionally, males in both countries appeared more likely to act unethically than female students. But the inclination towards unethical actions dropped dramatically when an element of risk was introduced, suggesting that the risk of getting caught would make individuals act more ethically. Factors that were believed to contribute to the differences between the respondents in the two countries include sensitivity of the business environments towards ethics issues, legal protection afforded to whistle blowers, and the emphasis on ethics through education.

Cohen et al. (2001) investigated the differences in an individual's ethical decision-making between university business students and accounting professionals. Using a series of examples, differences were measured on the three dimensions known to be important in the ethical decision making process, ethical awareness, ethical orientation, and intention to perform unethical acts. Although the groups displayed similar ethical orientation and ethical awareness levels, the latter was strongly related to the intention to commit unethical acts. Additionally, women consistently viewed the questionable acts presented as less ethical and, therefore, were less willing to perform them than were the men.

Ethics research typically measures what the participant thinks should be done and not what they would actually do in a given situation. Those attitudes are not necessarily a good reflection of actual behavior. Smith and Oakley (1997) found evidence relating to the potential effects of a "social desirability" response bias, where ethical attitudes, how they would act, are replaced with ethical principles, what they consider socially acceptable behavior. Kantor and Weisberg (2002) noted that researchers' continued efforts to predict behavior from a subject's opinion should always consider the gap between what the subject thinks "ought to be done" and their actual behavior. Additionally, people tend to evaluate themselves more favorably than others (Alicke et al., 1995), thus creating a 'self-enhancement bias', which is the tendency to describe oneself more positively than the social norm. Manley et a1. (2001) also noted that, based on prior research, self-enhancement bias can occur in studies involving ethics perceptions, but the bias is reduced when the factors of being caught and punished are present.

A review of the literature indicates that research focusing on factors that may influence ethical behavior produce conflicting results and that they are not able to accurately predict actual behavior. Considering these problems, the present survey instrument was designed to use two basic elements of Thome's model (Armstrong et al., 2003) that are thought to determine ethical behavior. They are moral development, ethics principles, (the ability to understand the issues, think them through and arrive at an ethical judgment), and virtue, personal values, (the ethical motivation and intention to act morally and the ethical character to bring that attention to realization). Virtue may be important in achieving internal satisfaction, such as blessedness, happiness and prosperity, but the possession of virtue may hinder the achievement of external satisfactions such as wealth, power and fame (McIntyre, 1984, as quoted by Libby and Thorne, 2002). This juxtaposition of internal and external satisfactions makes it impossible to maximize both, forcing choice between the two. Therefore, a person's dominant drive, internal or external achievement, would likely determine the ultimate decision or action. Another reason that 
decisions may not follow one's ethical values is the existence of conflicting organizational pressures (Allmon et al., 2000).

Based upon the "attribution theory," (Buckley et al. 1998) argued that individuals who believe they are ethical while simultaneously perceiving that unethical behavior is common, might as be inclined to engage in unethical behavior in order to compete on even ground despite believing that the actions are morally wrong. Nevertheless, the influences of the motivation, pressures and rationalization on unethical behavior are decreased if the individual is held accountable for his/her choices (Brief et al., 1990) and when a certain level of risk is associated with the action (Buckley et al., 1998).

The current study posits that when unethical behavior is observed, the observer would try to explain why the perpetrator acted unethically, the reason or motivation for the act. The observer would then arrive at either a positive or negative response, during which ethics principles and personal values could be of some influence. A positive response indicates agreement with the act or acceptance of the excuse given for the act. This ethical judgement implies that the respondent would exhibit similar behavior in similar situations.

Ahmad and Fadzly (A \& F) completed a study, with Malaysian students, to determine if ethics principles and personal values were related to ethical judgement and, if the perceived consequences of an unethical act might influence ethical judgement. A total of 347 students responded to their questionnaire, $81 \%$ of whom were females. They found that students thought ethics principles and personal values were two important factors affecting their behavior. In spite of being intolerant to bribery, most respondents indicated that cheating might be acceptable when needed, and that fraud should only be reported when the amount is significant.

The current framework proposes that individuals who respond negatively, do not endorse the reason given for the unethical action, might take the same unethical action if there is a paradigm of the need to do so to maintain some level of parity (e.g. "if others are doing it then I have to do it to compete on a level playing field"). This decision would also depend on the likelihood of some perceived consequences occurring. An individual who believes that unethical behavior will result in positive consequences would be more likely to commit an unethical act. Similarly, a person who perceives a high likelihood of receiving negative consequences would tend to be dissuaded from committing an unethical act. The present study examines business and accounting students' ethics principles, personal values and their perceptions of implications of unethical conduct.

\section{STUDY DESIGN}

The survey questionnaire used in the A \& F study was modified slightly to make it more appropriate for students attending a university in the U.S. and to change the demographic information requested. The previous study asked for "accounting work experience" which was not considered relevant in this study. Only about one percent of the respondents had more than one year of experience and almost $80 \%$ had no experience. Statements were added relating to ethnicity and religion to allow for analysis based on those factors. The instrument used contained 19 statements, relating to the five scales, and five demographic statements.

The questionnaire, containing 19 statements relating to the research issues and five demographic questions, is shown in Appendix I. A total of 418 undergraduate business and accounting students completed the questionnaire. Statements were randomly arranged as much as possible consistent with similar response scales. Table 1 contains responses to the statements grouped by the scales investigated.

As seen in table 1, the five scales were ethics principles, personal values, ethical judgment, perceived positive consequences and perceived negative consequences of unethical behavior. Each scale was measured by three to five statements.

The Ahmad and Fadzly (A \& F) study used these statements, or statements very similar, but did not indicate that any reliability testing had been done on the scales. All of the scales were subjected to reliability testing using Cronbach's "coefficient alpha." The first scale, ethics principles, contained the following three statements. 
- Honesty is always the best policy.

- $\quad$ Other people's welfare is more important than mine.

- I will never tolerate bribery in my life.

Cronbach's coefficient alpha for the scale was 0.430 and the elimination of any one of the three items would lower the alpha. Therefore, they were all retained as part of the scale for later analysis.

In the second scale, personal values, respondents were asked to indicate the level of importance for each of the following factors in their ethical decision making.

- $\quad$ Self-principles.

- Money.

- $\quad$ Religion.

- Law or regulations.

The initial Cronbach's coefficient alpha was 0.344 and the analysis indicated that if the second factor, relating to "money," was eliminated the alpha would increase to 0.396. Consequently, that factor was left out of the scale in additional data analysis.

The "money" factor was not strongly correlated with the other factors in the scale but it was significantly correlated (at the 0.05 level) with all of the five scales. That result indicates that it is an important factor in ethical decision making. No further analysis of the factor will be presented here.

Scale analysis of statements contained in the ethical judgment scale yielded a Cronbach's coefficient alpha of 0.654 . The following three statements were included in the scale.

- $\quad$ Reporting a financial malpractice is required only if it involves a lot of money.

- $\quad$ Bribery is acceptable if it is customary in the present environment.

- In some situations cheating is the right thing to do.

Results indicated that eliminating any one of the three statements would lower the coefficient so, all three statements were retained in the scale.

The final two scales related to potential positive and negative consequences of an action. The following statements were contained in the perceived positive consequences scale.

- I will get a lot of money.

- I will enjoy a better lifestyle..

- I will have better business opportunities.

- I will become more competitive.

Scale reliability analysis of the statements yielded a Cronbach's coefficient alpha of 0.877 and indicated that the scale would not be improved by eliminating any of the four statements.

The last scale was Perceived Negative Consequences of an action and the following statements made up the scale.

- $\quad$ I will be legally punished.

- I will commit a sin.

- $\quad$ I will lose my job.

- I will humiliate myself.

- I will humiliate my family. 
Analysis of the responses gave a Cronbach's coefficient alpha of 0.829 and indicated that the scale would be improved if the statement "I will commit a sin" was eliminated. Consequently, this statement was eliminated from the scale and the alpha increased to 0.886 .

Responses to this statement were positively correlated with personal values which is to be expected because if an individual believes they would commit a sin by performing an unethical act then they would also expect to have high personal values. However, responses were negatively correlated (at the 0.01 level) with the negative consequences scale which is surprising at first glance because an individual who considers committing a sin as a negative consequence of performing an unethical act would also consider the other four consequences in the same light. Upon closer inspection, however, committing a sin is spiritual while the other four are temporal punishments and, committing a sin is an action and not a punishment. This factor is not considered further in this study.

Each of these statements was correlated with some of the other statements but no analysis of those relationships was conducted for this study.

\section{RESULTS}

\section{Ethics Principles}

Responses to statements relating to ethics principles indicate that ethics is considered to be very important to the students surveyed. As can be seen in Figure 1, more than 92\% agreed that "honesty is the best policy," and about $74 \%$ said that they would "never tolerate bribery in their life." These results indicate that the students view themselves as having strong ethics and as being honest. Compared with the A \& F study, results were higher for "honesty" (92\% to $89 \%)$ and bribery $(74 \%$ to $72 \%)$ but, the difference does not appear significant. There were approximately 350 responses to the A \& F study compared with the 418 responses in the present study.

Responding to the statement that "Other people's welfare is more important than mine," students were substantially less supportive of the concept with only $57.66 \%$ in agreement. Apparently, even though they view themselves as being ethical, a large proportion (42\%) do not believe that other people's welfare is more important than their own welfare. Still, the percentage (57.66) agreeing was substantially higher than the $44.67 \%$ that agreed in the A \& F study. That study was conducted with students in a predominately Muslim country.

\begin{tabular}{ccccc} 
& \multicolumn{2}{c}{ Ethics Principles - Percent Agree } & Scale \\
Present & Honesty & Welfare & Bribery & $74.73 \%$ \\
A \& F & $92.57 \%$ & $57.66 \%$ & $73.98 \%$ & $68.67 \%$
\end{tabular}

The mean response for the scale was 4.326 which is between the "slightly agree" and "agree" points on the scale. 


\section{Ethics Principles Scale}

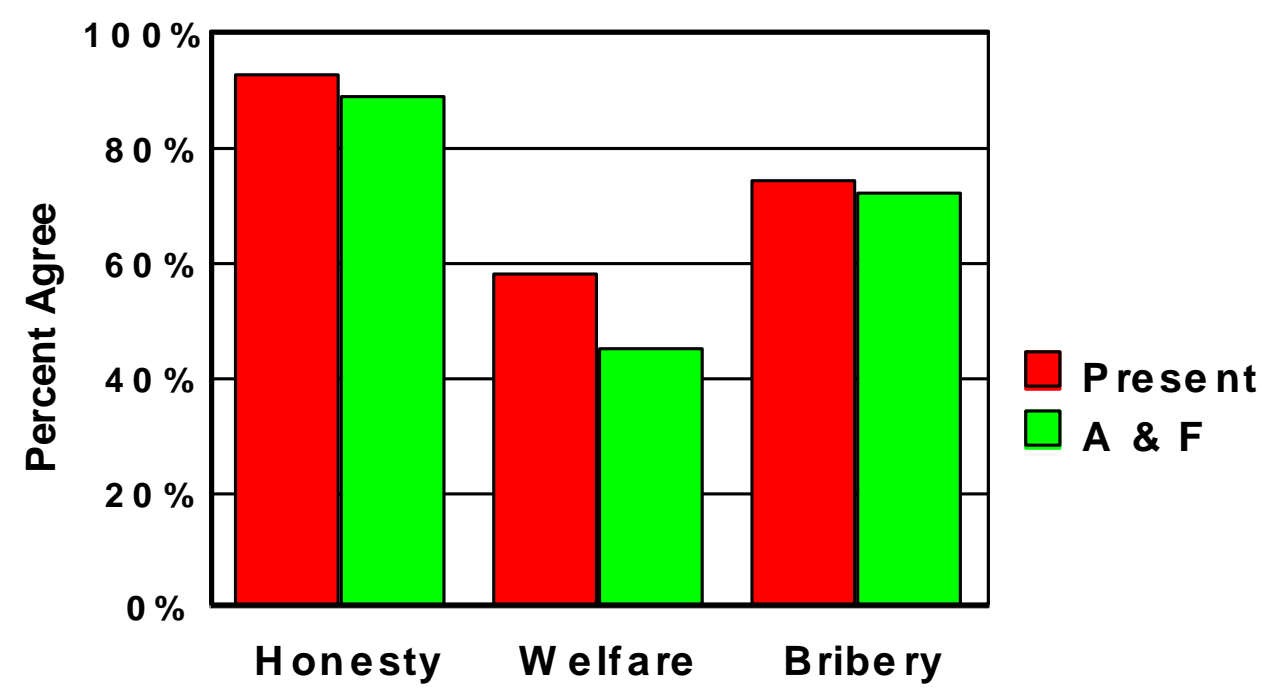

Figure 1

\section{Personal Values}

All four of the personal values scales were rated as being important in the students' ethical decision making. However, because the "money" scale reduced the scale reliability it was removed from the analysis. Response percentages to the other scales are shown below in Figure 2. More than 99\% indicated that "selfprinciples" were important when they made ethical decisions. This compares with 79.48\% for "religion" and 93.78\% for "law or regulations." Again, these percentages are higher than in the A \& F study. For "self-principles" A \& F had 94.24 compared 99.28 and 72.05 compared to 79.43 for "religion." While these differences may not be significant, the difference for "law and regulations" was substantial. In the A \& F study only $71.18 \%$ indicated that this factor was important in making ethical decisions while in the present study $93.78 \%$ so indicated. While a number of explanations for this difference are possible, one is that students in the present study believed that the probability of exposure and punishment was greater. This belief could result in a heightened importance of the factor in ethical decision making. Another explanation could be that the relatively high importance of "selfprinciples" and "religion" overshadowed the need for "law and regulations" to be as important in the A \& F study. However, the importance of both of these factors was higher in the present study.

\begin{tabular}{ccccc}
\multicolumn{4}{c}{ Personal Values - Percent Important } \\
Present & Self-Principles & Religion & Law \& Regulation & Scale \\
A \& F & $99.28 \%$ & $79.43 \%$ & $93.78 \%$ & $90.83 \%$ \\
& $94.24 \%$ & $72.05 \%$ & $71.18 \%$ & $79.16 \%$
\end{tabular}




\section{Personal Values Scale}

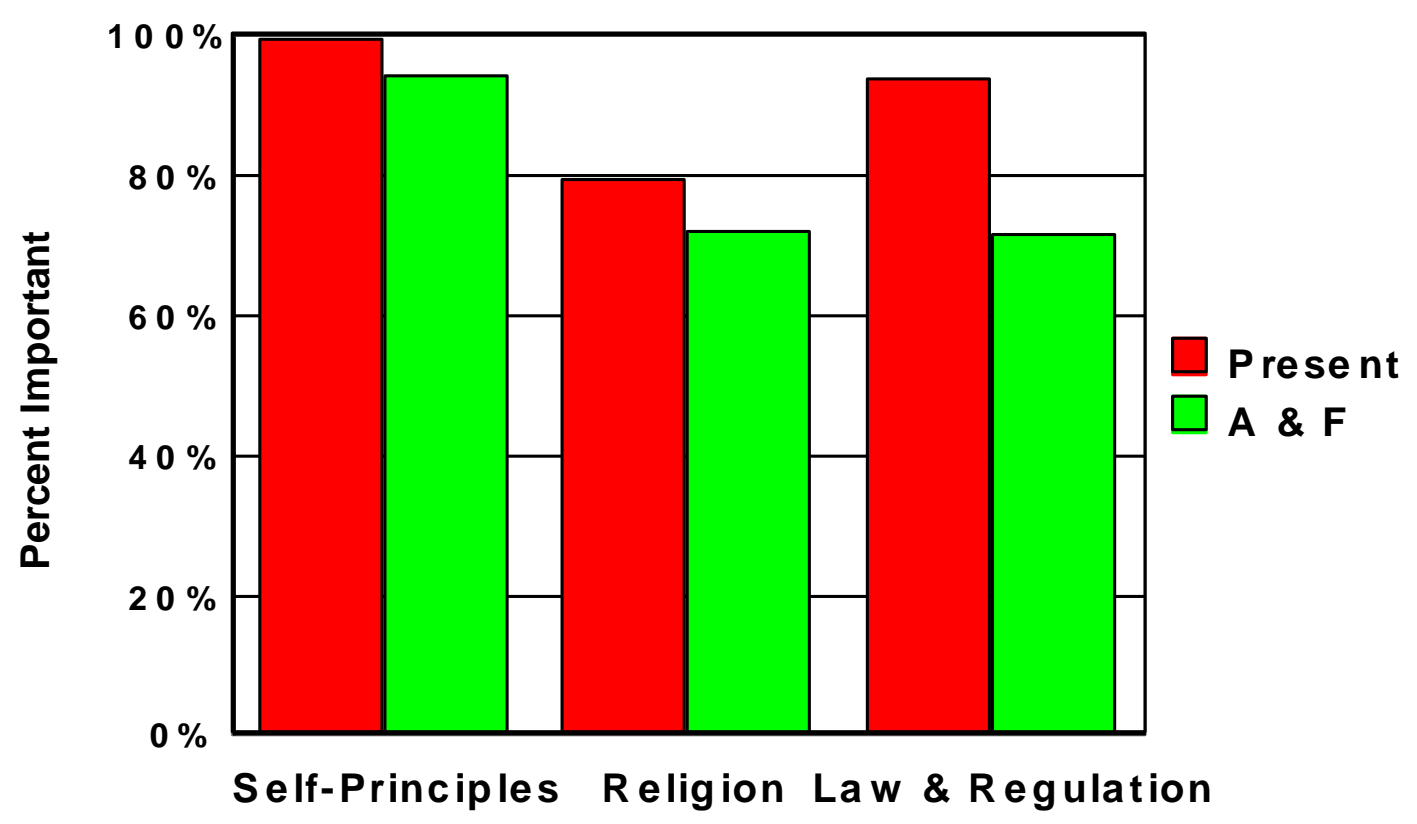

Figure 2

\section{Ethical Judgment}

The ethical judgment scale contained statements that made excuses for acts that would normally be considered unethical. These excuses can be seen in Table 1 and they are abbreviated in Figure 3 below. Given the relatively high levels of ethics principles and personal values indicated previously, respondents would be expected to reject these excuses. Overall that observation is correct because less than half of the respondents agreed that these excuses were acceptable reasons for unethical behavior. However, the difference between the two samples is surprising. As can be seen, respondents in the A \& F study accepted these excuses as valid one and one-half to three tines as often. Only $15.32 \%$ of respondents in the present study agreed that "reporting a financial malpractice is required only if it involves a lot of money" while a surprising $45.31 \%$ in the A \& F study agreed. Responses to the statement that "bribery is acceptable if it is customary in the present environment" were only about $50 \%$ greater (34.43\% to $23.80 \%$ ) for the A \& F study. For the last statement relating to the ethical judgment scale, "in some situations cheating is the right thing to do," respondents in the A \& F study endorsed the excuse two and one-half times as often as students in the present study. Recall that responses to the ethics principles and personal values scales were very similar. The surprising differences may be due to cultural differences of the respondents and responses to the positive and negative consequences of unethical acts may help clarify this possibility.

$\begin{array}{ccccc} & \text { Report Malpractice } & \begin{array}{c}\text { Ethical Judgment } \\ \text { Accept Bribery }\end{array} & \text { Cheating } & \text { Scale } \\ \text { Present } & 15.31 \% & 23.80 \% & 17.94 \% & 19.02 \% \\ \text { A \& F } & 45.24 \% & 33.43 \% & 46.11 \% & 41.59 \%\end{array}$




\section{Ethical Judgement}

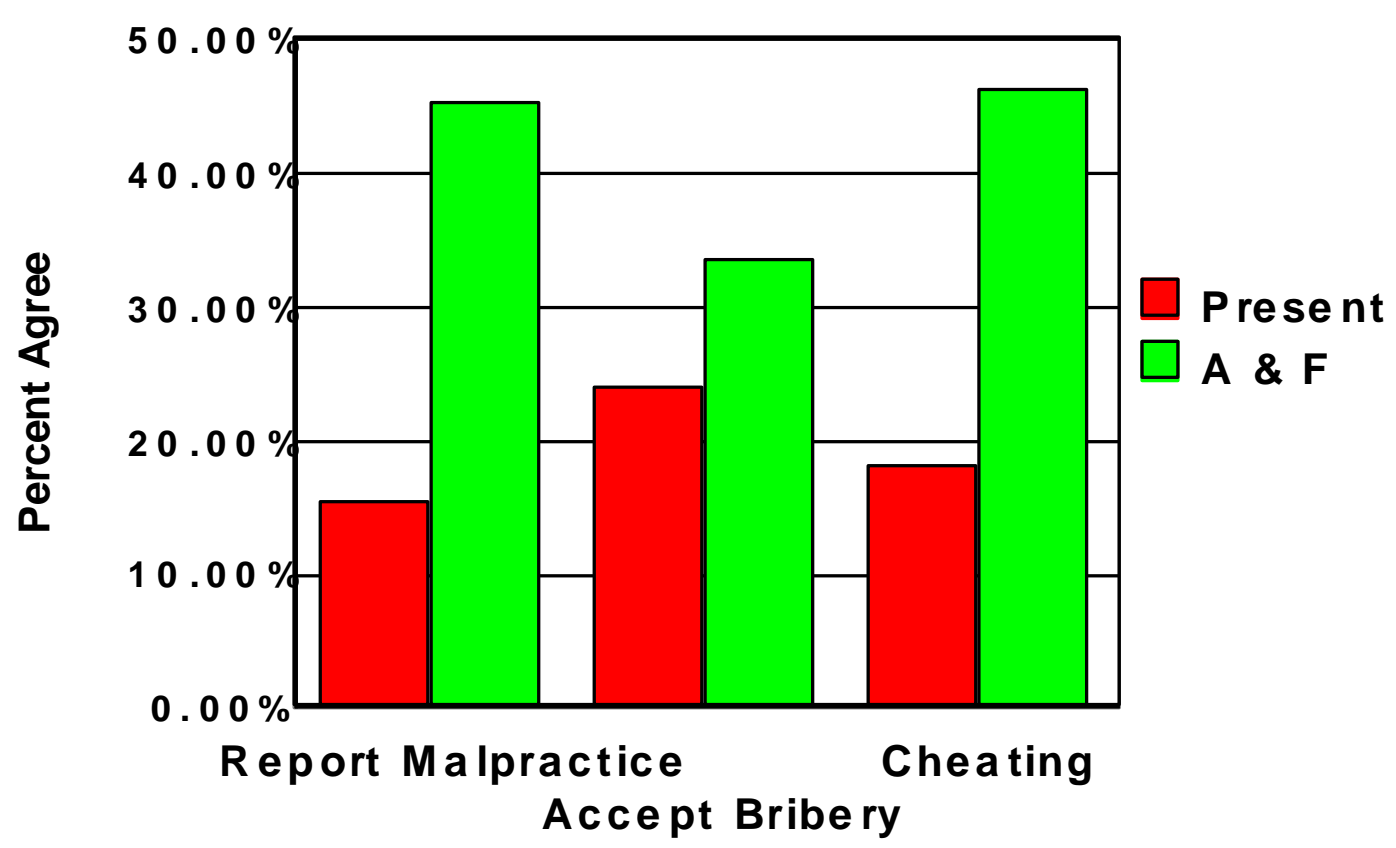

Figure 3

\section{Positive Consequences}

Respondents were asked to indicate how likely (or unlikely) you think the following consequences of unethical behavior are for you. They were then given a list of four positive consequences and five negative consequences. As demonstrated in Figure 4, except for becoming more competitive, respondents in the A \& F study believed more strongly that they would benefit from unethical behavior. This difference may account for the higher level of acceptance, noted in the ethical judgment scale, of the excuses for unethical behavior.

\begin{tabular}{cccccc} 
& \multicolumn{4}{c}{ Positive Consequences } \\
More Money & Better Lifestyle & Better Opportunity & More Competitive & Scale \\
Present & $57.38 \%$ & $56.20 \%$ & $60.96 \%$ & $61.69 \%$ & $59.06 \%$ \\
A \& F & $78.70 \%$ & $71.80 \%$ & $66.60 \%$ & $49.00 \%$ & $66.53 \%$
\end{tabular}

However, it is surprising that after displaying high levels of ethics principles and personal values more than half of the respondents in the present study and about two-thirds in the A \& F study believe they would benefit from unethical behavior. An interesting difference in the two studies is that more respondents in the present study believed that engaging in unethical behavior would make them more competitive. 


\section{Positive Consequence of Unethical Actions}

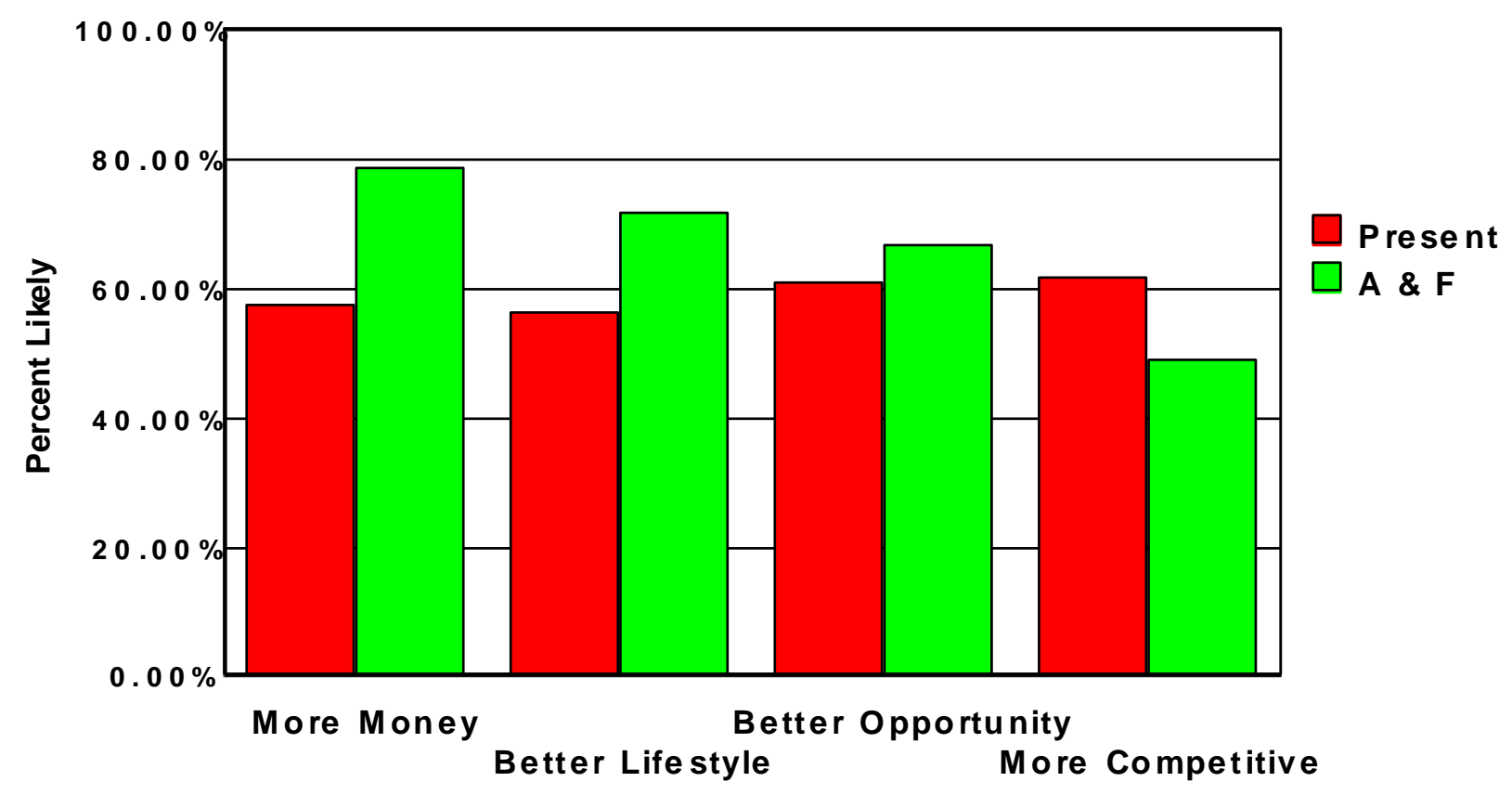

Figure 4

\section{Negative Consequences}

The negative consequences scale contained statements relating to five factors but, as discussed earlier, the factor "I will commit a sin" was removed. As seen in Figure 5, participants in the A \& F study believe more strongly that all of the negative factors will result from unethical behavior than do the respondents in the present study. Those results suggest that they believe they are likely to be caught and that the positive benefits of unethical behavior will be short-lived. Interestingly, the strongest negative consequence for the A \& F study was "I will humiliate my family" while for the present study it was "I will humiliate myself." Perhaps this is an interesting reflection of cultural differences between the Asian, family-oriented, and American self-oriented culture.

$\begin{array}{cccccc} & \text { Legally Punished } & \text { Lose My Job } & \text { Humiliate Myself } & \begin{array}{c}\text { Humiliate } \\ \text { My Family }\end{array} & \text { Scale } \\ \text { Present } & 55.80 \% & 55.18 \% & 61.84 \% & 51.69 \% & 56.13 \% \\ \text { A \& F } & 74.60 \% & 68.90 \% & 68.60 \% & 82.90 \% & 73.75 \%\end{array}$




\section{Negative Consequences of Unethical Actions}

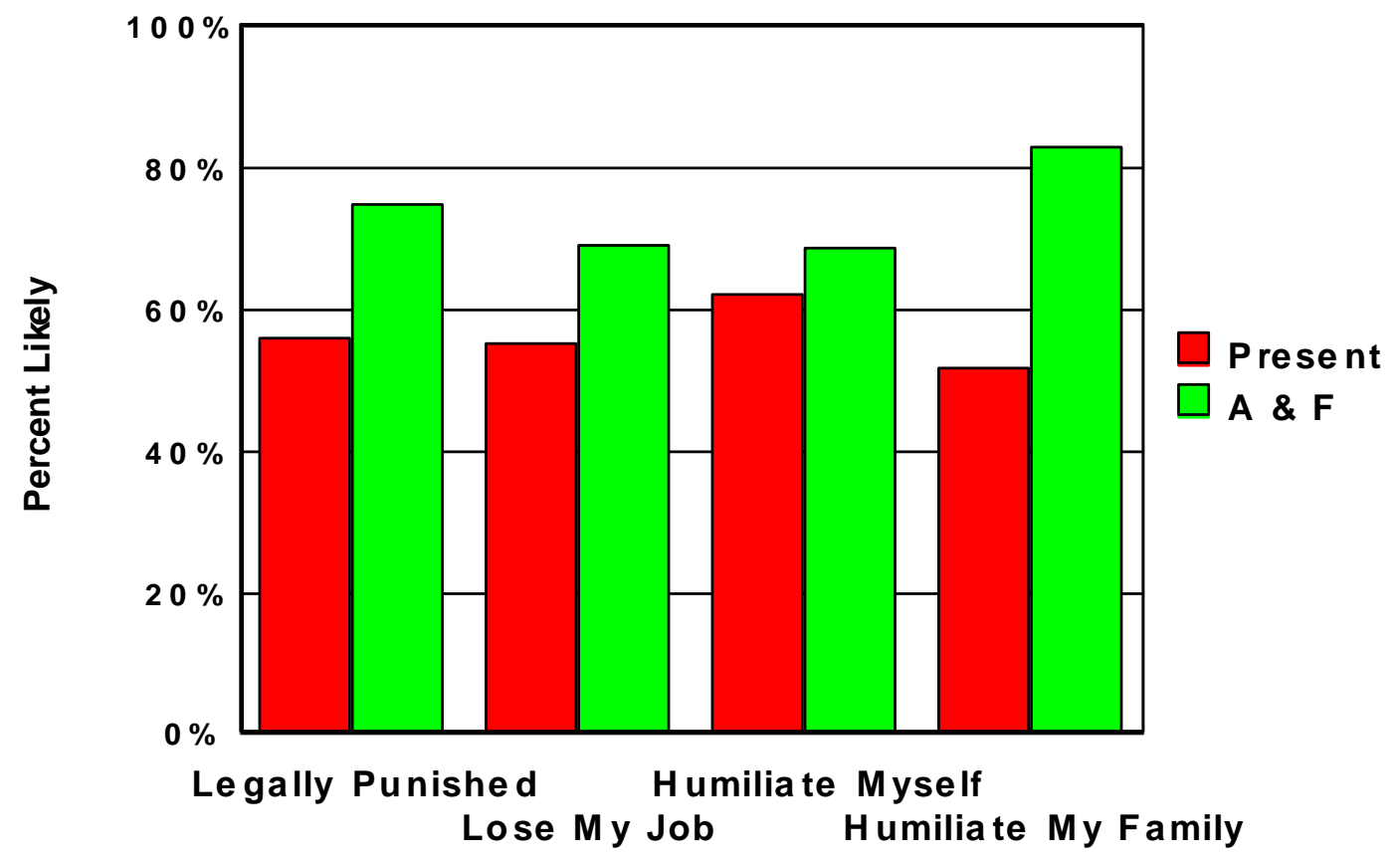

Figure 5

\section{Relationships Between the Scales}

Ahmad and Fadzly hypothesized that when a person observes what they consider to be an unethical act they will try to explain (ethical judgment) why the individual acted unethically. The person would then either endorse the action as acceptable in the circumstances or reject it as unacceptable. Their ethics principles (virtue) and personal values would supposedly influence that decision. Additionally, the authors suggest that the perceived consequences of the unethical act would also have an influence. Correlation coefficients were calculated for the relationships between the scales and are shown in Table 2 .

As expected the ethics principles and personal values scales were highly correlated, at the 0.000 level. Additionally, they were both negatively correlated (at 0.000 level) with the ethical judgment scale. These results indicate that the respondents who indicated a high level of ethics and a high level of personal values rejected the excuses for unethical behaviors given in the ethical judgment scale statements. Conversely, those participants exhibiting a lower level of ethics and personal values would be more accepting of the excuses for unethical behavior.

The "positive consequences of unethical actions" scale was negatively correlated (at the 0.000 level) with the ethics principles, personal values and the negative consequences of unethical actions scales. The correlation was positive, and significant at the 0.001 level, with the ethical judgment scale. This indicates that participants who thought they would benefit from unethical actions displayed lower ethics principles, lower personal values, and were more likely to accept, and excuse, unethical actions on the part of others. The significant relationship between positive consequences of unethical actions and negative consequences of unethical actions is logical. If a person believes that they will benefit from an unethical action then it is reasonable to believe that they would think the negative consequences (legally punished, lose my job, etc.) would be unlikely. 


\section{Gender Differences}

In the present study $48.2 \%$ of the respondents were females while in the A \& F study $81 \%$ of the participants were female. Significant differences were found, in the present study, between the responses of males and females for the personal values and the ethical judgment scales. Females displayed stronger personal values and were less accepting of excuses for unethical actions. Consequently, the difference between the percentage of females in the present study and the A \& F study does not explain the greater tolerance of respondents in the A \& F study in accepting the excuses for unethical actions.

\section{SUMMARY AND CONCLUSIONS}

Respondents in the present study indicated a high level of ethics principles with an average of $74.73 \%$ agreeing with the items in the scale. Responses to the items in the personal values scale were even higher with an average of $90.83 \%$ of the participants indicating that the factors were important in their ethical decision making. These percentages are substantially higher than those reported in the A \& F study, $68.67 \%$ for ethics principles and $79.16 \%$ for personal values, for a predominately female student sample in Malaysia.

The ethical judgment scale reflects the level of acceptance of (making excuses for) unethical acts. Only $19.02 \%$ of the participants in the present study indicated that they would agree that the unethical acts contained in the scale were acceptable in the environment described. Recall that the statements were "reporting a financial malpractice is required only if it involves a lot of money," "bribery is acceptable if it is customary in the present environment," and "in some situations cheating is the right thing to do." These results are consistent with the high levels of ethics principles and personal values. However, on average more than twice as many respondents in the A \& F study $(41.59 \%)$ agreed that these excuses were acceptable. That is surprising given that the indicated levels of ethics principles and personal values were about the same for the two groups.

Almost $60 \%$ of the respondents in the present study believed that they would experience positive consequences from unethical actions and a similar number, 56.13\%, believed that they would experience negative consequences from unethical actions. Apparently they believe the benefits of acting unethically are short-lived and that they will suffer consequences such as being humiliated or losing their job. Responses in the A \& F study were stronger (believed more likely to occur) for both of the scales, $66.53 \%$ and $73.75 \%$ respectively, and stronger for all of the items in the scales except for "I will become more competitive." Perhaps respondents in the A \& F study see the benefits and being primarily monetary in nature.

The ethics principles and personal values scales were both negatively correlated, at the 0.000 level, with the ethical judgment scale. Those results indicate that they both are likely to be factors in making ethical judgments. The higher the values for ethics principles and personal values the less accepting respondents were of the excuses for unethical behavior. Additionally, the two scales were negatively correlated, at the 0.000 level, with the positive consequences of unethical actions scale indicating that those with higher the ethics and personal values tended to see less positive benefit of unethical actions. They were also positively correlated with the negative consequences of unethical actions scale, at the 0.090 level for ethics and 0.000 level. This suggests that individuals with high ethics and values expect that punishment for unethical action is more likely.

In summary, respondents indicated a high level of ethics principles and personal values and those with higher levels were less accepting of excuses for unethical behavior. Participants in the A \& F study were more accepting of excuses for unethical behavior, believed that the positive benefits of unethical actions were more likely, and that the negative benefits of unethical actions were more likely.

\section{REFERENCES}

1. Ahmad, Zauwiyah \& Fadzly, Mohamed Nazri F., presented at the $5^{\text {th }}$ Annual Conference of the Asian Academic Accounting Association, October 11-13, 2004. 
2. Alicke, Mark D, (1995). Personal contact, individuation, and the better-than-average effect, Journal of Personality and Social Psychology, v 68, no 5, 804-825.

3. Allmon, D.E., Page, D., \& Roberts, R. (2000). Determinants of perceptions of cheating: Ethical orientation, personality and demographics. Journal of Business Ethics, 23 (4), pp. 41 1-422.

4. Armstrong, M.B., Ketz, 1.E., \& Owsen, D. (2003). Ethics education in accounting: moving toward ethical motivation and ethical behavior. Journal of Accounting Education, 21, pp. 1-16.

5. Brief, A. Dukerich, J., \& Doran, L. (J 990). Resolving ethical dilemmas in management: experimental investigation of values, accountability and choice. Journal of Applied Social Psychology, 21(5), pp. 380396.

6. Buckley, M.R., Wiese, D.S., \& Harvey, M.G. (1998). An investigation into the dimensions of unethical behavior. Journal of Education for Business, May/June, pp. 284-290.

7. Cohen, J. R., Pant, L.W., \& Sharp, D.J. (2001). An examination of differences in ethical decision-making between Canadian business students and accounting professionals. Journal of Business Ethics, 30 (4), pp. 319-336.

8. Glover, S.H., Bumpus, M.A., Sharp, G.F, \& Munchus, G.A. (2002). Gender differences in ethical decision making. Women in Management Review, 17(5), pp. 217-227.

9. Kantor, J. \& Weisberg, 1. (2002). Ethical attitudes and ethical behavior: Are managers role models? International Journal of Manpower, 23 (8), pp. 687-793.

10. Libby, T. \& Thome, L. (2002). Auditors' virtue and professional role behaviors: The development of a measure of auditors' virtue and an examination of associated outcomes. Paper presented at the Annual Professionalism and Ethics Symposium, American Accounting Association 2002 Annual Meeting, August.

11. Manley, G.G., Russel, C.J., \& Buckley, M.R. (2001). Self-enhancing in perceptions of behaving unethica11y. Journal of Education for Business, 77 (1), pp. 21-27.

12. O'Leary, C. \& Cotter, D. (2000). The ethics of final year accountancy students: An international comparison. Managerial Auditing Journal, 15 (3), pp. 108-115.

13. Sankaran, S. \& Bui, T. (2003). Relationship between students characteristics and ethics:Implications for educators. Journal of Instructional Psychology, 30 (3), pp. 240-253.

14. Smith, P.L. \& Oakley, E.F. (1997). Gender-related differences in ethical and social values of business students: Implications for management. Journal of Business Ethics, J 6, pp. 37-45. 
Table 1: Percentage Responses to Statements in Each Scale

\begin{tabular}{|c|c|c|c|c|c|c|}
\hline \multicolumn{7}{|c|}{ Ethics Principles } \\
\hline Please indicate your level of agreement with each of the following statements. & $\begin{array}{l}\text { Strongly } \\
\text { Disagree }\end{array}$ & Disagree & $\begin{array}{c}\text { Slightly } \\
\text { Disagree }\end{array}$ & $\begin{array}{c}\text { Slightly } \\
\text { Agree }\end{array}$ & Agree & $\begin{array}{c}\text { Strongly } \\
\text { Agree }\end{array}$ \\
\hline Honesty is always the best policy. $n=417$, mean $=5.02$ & 2.64 & 1.20 & 3.60 & 7.91 & 53.00 & 31.65 \\
\hline Other people's welfare is more important than mine. $n=418$, mean $=3.65$ & 3.11 & 15.07 & 24.16 & 31.82 & 22.97 & 2.87 \\
\hline I will never tolerate bribery in my life. $n=415$, mean $=4.31$ & 0.48 & 9.16 & 16.39 & 24.58 & 31.81 & 17.59 \\
\hline
\end{tabular}

\begin{tabular}{|c|c|c|c|c|c|c|}
\hline \multicolumn{7}{|c|}{ Personal Values } \\
\hline $\begin{array}{l}\text { Please indicate the level of importance each of the following factors has in your } \\
\text { ethical decision making. }\end{array}$ & $\begin{array}{l}\text { Not At All } \\
\text { Important }\end{array}$ & Unimportant & $\begin{array}{c}\text { Slightly } \\
\text { Unimportant }\end{array}$ & $\begin{array}{l}\text { Slightly } \\
\text { Important }\end{array}$ & Important & $\begin{array}{c}\text { Very } \\
\text { Important }\end{array}$ \\
\hline Self-principles. $n=418$, mean $=5.41$ & 0.00 & 0.24 & 0.48 & 3.83 & 48.56 & 46.89 \\
\hline Money. $n=418$, mean $=4.44$ & 1.91 & 7.66 & 5.50 & 30.38 & 39.00 & 15.55 \\
\hline Religion. $n=418$, mean $=4.53$ & 5.02 & 9.33 & 6.22 & 17.94 & 30.14 & 31.34 \\
\hline Law or regulations. $n=418$, mean $=4.95$ & 1.44 & 1.20 & 3.59 & 16.99 & 48.09 & 28.71 \\
\hline
\end{tabular}

Law or regulations. $n=418$, mean $=4.95$

Ethical Judgement

\begin{tabular}{|c|c|c|c|c|c|c|}
\hline Please indicate your level of agreement with each of the following statements. & $\begin{array}{l}\text { Strongly } \\
\text { Disagree }\end{array}$ & Disagree & $\begin{array}{l}\text { Slightly } \\
\text { Disagree }\end{array}$ & $\begin{array}{c}\text { Slightly } \\
\text { Agree }\end{array}$ & Agree & $\begin{array}{l}\text { Strongly } \\
\text { Agree }\end{array}$ \\
\hline $\begin{array}{l}\text { Reporting a financial malpractice is required only if it involves a lot of money. } n=418 \text {, } \\
\text { mean }=2.20\end{array}$ & 29.43 & 46.41 & 8.85 & 7.42 & 5.98 & 1.91 \\
\hline $\begin{array}{l}\text { Bribery is acceptable if it is customary in the present environment. } \\
n=416, \text { mean }=2.54\end{array}$ & 19.95 & 37.26 & 18.99 & 17.07 & 6.49 & 0.24 \\
\hline In some situations cheating is the right thing to do. $n=418$, mean $=2.29$ & 27.75 & 39.95 & 14.35 & 12.44 & 4.55 & 0.96 \\
\hline
\end{tabular}

In some situations cheating is the right thing to do. $n=418$, mean $=2.29$

\section{Perceived Positive Consequences}

\begin{tabular}{|c|c|c|c|c|c|c|}
\hline $\begin{array}{l}\text { Please indicate how likely you think the following consequences of unethical } \\
\text { behavior are. }\end{array}$ & $\begin{array}{l}\text { Highly } \\
\text { Unlikely }\end{array}$ & Unlikely & $\begin{array}{l}\text { Slightly } \\
\text { Unlikely }\end{array}$ & $\begin{array}{l}\text { Slightly } \\
\text { Likely }\end{array}$ & Likely & $\begin{array}{l}\text { Highly } \\
\text { Likely }\end{array}$ \\
\hline I will get a lot of money. $n=413$, mean $=3.54$ & 7.75 & 22.52 & 12.35 & 29.54 & 21.55 & 6.30 \\
\hline I will enjoy a better lifestyle. $n=411$, mean $=3.54$ & 10.46 & 23.36 & 9.98 & 23.36 & 23.84 & 9.00 \\
\hline I will have better business opportunities. $n=415$, mean $=3.69$ & 6.27 & 22.65 & 10.12 & 24.82 & 29.16 & 6.99 \\
\hline I will become more competitive. $n=415$, mean $=3.83$ & 6.51 & 18.07 & 13.73 & 21.69 & 27.47 & 12.53 \\
\hline
\end{tabular}

I will become more competitive. $n=415$, mean $=3.83$

Perceived Negative Consequences

\begin{tabular}{|c|c|c|c|c|c|c|}
\hline $\begin{array}{l}\text { Please indicate how likely you think the following consequences of unethical } \\
\text { behavior are. }\end{array}$ & $\begin{array}{l}\text { Highly } \\
\text { Unlikely }\end{array}$ & Unlikely & $\begin{array}{l}\text { Slightly } \\
\text { Unlikely }\end{array}$ & $\begin{array}{l}\text { Slightly } \\
\text { Likely }\end{array}$ & Likely & $\begin{array}{l}\text { Highly } \\
\text { Likely }\end{array}$ \\
\hline I will be legally punished. $n=414$, mean $=3.59$ & 17.87 & 17.15 & 9.18 & 12.56 & 30.68 & 12.56 \\
\hline I will commit a sin. $n=413$, mean $=4.44$ & 6.54 & 8.47 & 8.96 & 16.22 & 30.02 & 29.78 \\
\hline I will lose my job. $n=415$, mean $=3.60$ & 12.29 & 20.48 & 12.05 & 17.11 & 26.51 & 11.57 \\
\hline I will humiliate myself. $n=414$, mean $=3.93$ & 7.00 & 16.91 & 14.25 & 15.46 & 30.92 & 15.46 \\
\hline I will humiliate my family. $n=414$, mean $=3.53$ & 17.39 & 20.05 & 10.87 & 12.56 & 30.92 & 15.56 \\
\hline
\end{tabular}


Table 2: Correlation Coefficients Between the Scales and Significance Level

\begin{tabular}{|c|c|c|c|c|c|}
\hline & $\begin{array}{c}\text { Ethics } \\
\text { Principles }\end{array}$ & $\begin{array}{c}\text { Personal } \\
\text { Values }\end{array}$ & $\begin{array}{c}\text { Ethical } \\
\text { Judgement }\end{array}$ & $\begin{array}{c}\text { Positive } \\
\text { Consequences }\end{array}$ & $\begin{array}{c}\text { Negative } \\
\text { Consequences }\end{array}$ \\
\hline $\begin{array}{l}\text { Ethics } \\
\text { Principles }\end{array}$ & $\begin{array}{l}1.000 \\
\mathrm{n}=414\end{array}$ & $\begin{array}{c}0.230 \\
0.000 \\
\mathrm{n}=410\end{array}$ & $\begin{array}{c}-0.444 \\
0.000 \\
n=412\end{array}$ & $\begin{array}{c}-0.297 \\
0.000 \\
n=406\end{array}$ & $\begin{array}{c}0,084 \\
0.090 \\
\mathrm{n}=410\end{array}$ \\
\hline $\begin{array}{l}\text { Personal } \\
\text { Values }\end{array}$ & $\begin{array}{c}0.230 \\
0.000 \\
n=410\end{array}$ & $\begin{array}{l}1.000 \\
n=414\end{array}$ & $\begin{array}{c}-0.295 \\
0.000 \\
n=412\end{array}$ & $\begin{array}{c}-0.332 \\
0.000 \\
n=409\end{array}$ & $\begin{array}{c}0.640 \\
0.000 \\
\mathrm{n}=413\end{array}$ \\
\hline $\begin{array}{l}\text { Ethical } \\
\text { Judgement }\end{array}$ & $\begin{array}{c}-0.444 \\
0.000 \\
n=412\end{array}$ & $\begin{array}{c}-0.295 \\
0.000 \\
n=412\end{array}$ & $\begin{array}{l}1.000 \\
\mathrm{n}=416\end{array}$ & $\begin{array}{c}0.363 \\
0.000 \\
\mathrm{n}=408\end{array}$ & $\begin{array}{c}-0.168 \\
0.001 \\
n=411\end{array}$ \\
\hline $\begin{array}{l}\text { Positive } \\
\text { Consequences }\end{array}$ & $\begin{array}{c}-0.297 \\
0.000 \\
n=406\end{array}$ & $\begin{array}{c}-0.332 \\
0.000 \\
n=409\end{array}$ & $\begin{array}{c}0.363 \\
0.000 \\
n=408\end{array}$ & $\begin{array}{l}1.000 \\
\mathrm{n}=410\end{array}$ & $\begin{array}{c}-0.468 \\
0.000 \\
n=408\end{array}$ \\
\hline $\begin{array}{l}\text { Negative } \\
\text { Consequences }\end{array}$ & $\begin{array}{c}0.084 \\
0.090 \\
n=410\end{array}$ & $\begin{array}{c}0.640 \\
0.000 \\
n=413\end{array}$ & $\begin{array}{c}-0.168 \\
0.001 \\
n=411\end{array}$ & $\begin{array}{c}-0.468 \\
0.000 \\
n=408\end{array}$ & $\begin{array}{l}1.000 \\
n=413\end{array}$ \\
\hline
\end{tabular}

\section{NOTES}

